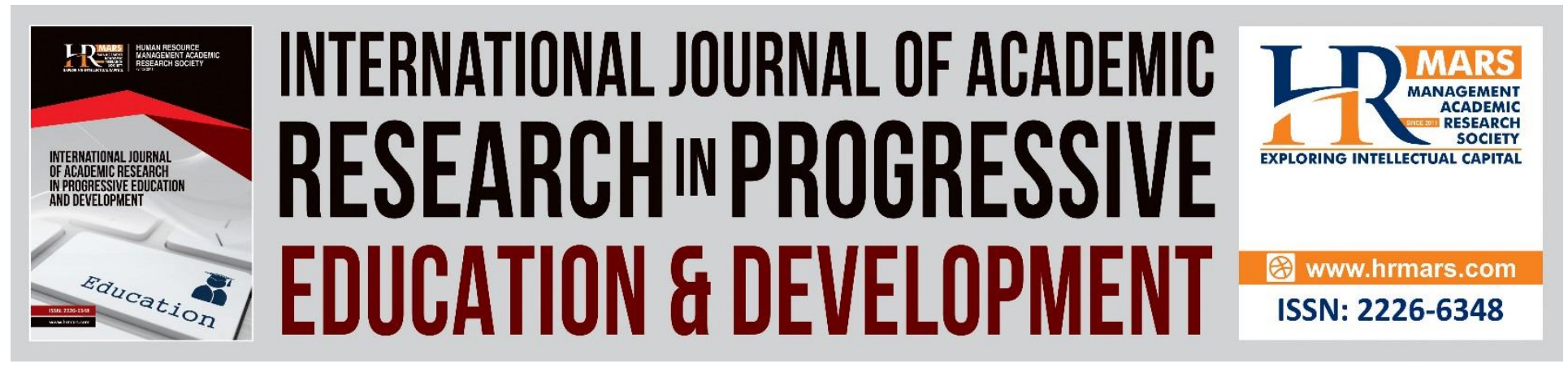

\title{
A Systematic Review of Using Technology in Learning English Language
}

\author{
Wee Shin Ang, Melor Md Yunus
}

To Link this Article: http://dx.doi.org/10.6007/IJARPED/v10-i1/9138

DOI:10.6007/IJARPED/v10-i1/9138

Received: 31 December 2020, Revised: 27 January 2021, Accepted: 15 February 2021

Published Online: 28 February 2021

In-Text Citation: (Ang \& Yunus, 2021)

To Cite this Article: Ang, W. S., \& Yunus, M. M. (2021). A Systematic Review of Using Technology in Learning English Language. International Journal of Acdemic Research in Progressive Education and Development, 10(1), 470-484.

Copyright: (C) 2021 The Author(s)

Published by Human Resource Management Academic Research Society (www.hrmars.com)

This article is published under the Creative Commons Attribution (CC BY 4.0) license. Anyone may reproduce, distribute, translate and create derivative works of this article (for both commercial and non-commercial purposes), subject to full attribution to the original publication and authors. The full terms of this license may be seen at: http://creativecommons.org/licences/by/4.0/legalcode

Vol. 10(1) 2021, Pg. 470 - 484

http://hrmars.com/index.php/pages/detail/IJARPED

JOURNAL HOMEPAGE

Full Terms \& Conditions of access and use can be found at http://hrmars.com/index.php/pages/detail/publication-ethics 


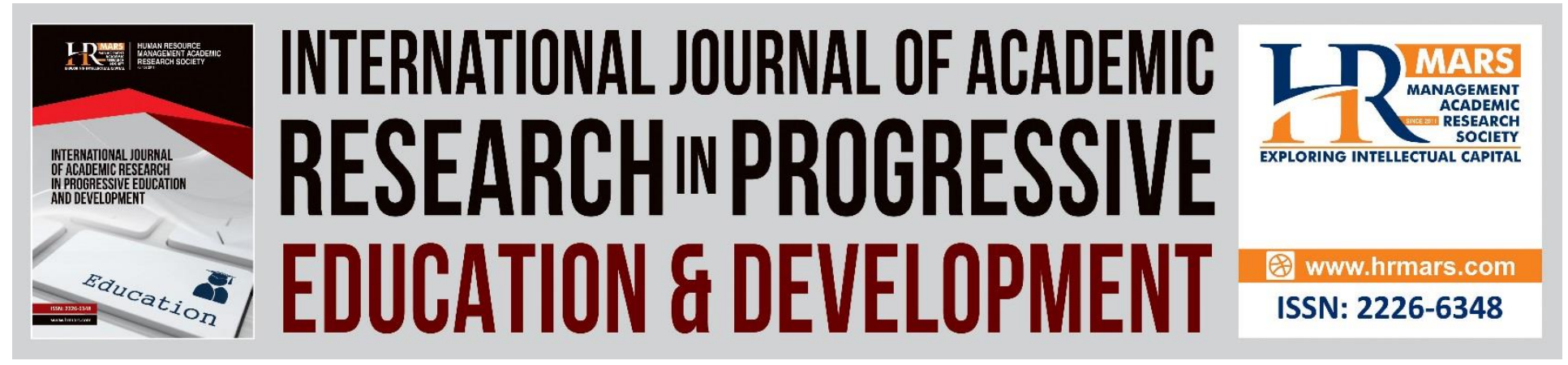

\title{
A Systematic Review of Using Technology in Learning English Language
}

\author{
Wee Shin Ang, Melor Md Yunus \\ Faculty of Education, Universiti Kebangsaan Malaysia, 43650 Selangor, MALAYSIA \\ Email:weeshinang@gmail.com,melor@ukm.edu.my
}

\begin{abstract}
In the era of $21^{\text {st }}$ century, technology has replaced the old-style teaching tools like textbooks and blackboard. The digital classroom is now promoted as a new trend in current educational policies. This paper takes a systematic approach to access the students' perceptions on the use of technology in learning English and factors influencing "e-learning". This paper was analysed and synthesised thoroughly with 21 articles chosen from the year 2016 until 2020 from the databases Eric and Google Scholar. Most of the studies used quantitative and mixed method in exploring the students' perception on the use of technology in learning English and factors influencing "elearning". In general, most of the users established the same perception as the technology does help the learning of English language.

Keywords: E-learning, English Language, Education, Systematic Approach, Students' Perception, Influencing Factors

\section{Introduction}

The growing access to the Internet and technology has led the transformation from traditional classroom to e-learning. E-learning includes online teaching and learning which engage the learners in the learning process through Internet and digital media (Stephenson, 2018). E-learning is mobile learning through mobile computational devices. Learning could happen anywhere and anytime with the advance of technology as long as the electronic devices are by your side. Mobile equipment like smart phones, laptops and tablets are the living necessities and the process of learning has changed by these electronic devices. Technologybased learning is believed to be an innovative learning technique for primary and secondary schools. However, it is more common in the higher-level education. Teaching and learning using technology make the process more interactive and collaborative. The use of ICT in education now is to help teachers to do administrative tasks more competently and students to learn more efficiently (Selwyn, 2003). Learners learn by doing rather than memorizing facts. They could join in tech-enabled group discussion, take an interactive quiz, play educational games, use virtual lab to perform science experiments or take a virtual field trip.
\end{abstract}


Due to increasing competition among nations in the world and globalization, English as the international language becoming more significant each day. Hence, there is a need for the relevant authorities to enhance the standard of the language in the country (Faradila, 2010). The English language considers to be the leading languages over the world because of its usage in all sectors like Medical, Business, Media, Education and so on. It is also the most commonly spoken language in the world. Learners need to have the opportunities to interact in English in order to enhance their learning, so that using technology will be good in assisting the learners especially for the second and foreign language learners. Technology gives an environment which helps the learners to increase their knowledge and creativity.

There are new challenges and duties to the teachers in the current era as the teaching methods have changed over the years. The entry of the innovative technologies has changed the style of English language instruction nowadays. Technology provides the opportunities for teachers to be more creative and thought-provoking in terms of constructive changes. The current teaching method focuses more on learner-centered which means less focus on the teachers. Heflin, Shewmaker \& Nguyen (2017) stated that teachers get the chances to re-imagine teaching and learning with the application of mobile technology. Learners need to be active in learning as they are responsible to their own learning and knowledge. The integration of information and communication technologies (ICT) can help revitalize teachers and students (Lin \& Yunus, 2012). With the help of technology, it supports learning by motivating students in learning, increasing access to information, helping in deeper understanding and improving problem solving abilities. Teachers act as the facilitator to give students tools to acquire knowledge and recognize the value of what they learn in books or Internet (Bancheri, 2006). In addition, Jeong (2006) highlighted the important role of teachers to motivate students in creating meaningful, nonthreatening and affectively supportive language learning environments by using Web technology. Therefore, teachers must require collaborative projects and development of intervention change strategies which incorporates teaching with technology to expand their teaching skills.

The growth of new technologies and digital media affect the new generations intensely. Their lives intermingled with the information technology and Internet as 'Digital natives' (Prensky, 2001), since they are born. According to (Liton, 2014), students in the present day engrained in multimedia and have acquired "hyperlinked minds". As a result, integrating technology in the learning process is essential in developing students' educational effectiveness. There are numbers of reports recounted the benefits of using technology in the classroom which include mastery of basic skill, more student-centered learning, increase task engagement and motivation, developing higher-order thinking skills, improvement in self-concept and active processing (Stepp-Greany, 2002). On the other hand, students appear to gain self-confidence to direct their own learning by using technology in the learning process. To make sure does the technology really facilitate the students in learning, it is important to know the perception of students on this approach.

Despite of the advantages of technology in teaching and learning, there are many problems to overcome before it could be integrated into the curriculum. Some might find that the process of integration is time consuming and frustrating. The factors that affect e-learning might fall on teachers, students or any external factors while learning using technology. Through 
a descriptive survey, Makokha \& Mutisya (2016) found that low interactivity and unsuccessful implementation of e-learning in public universities are because of the poorly designed courses. The challenges that might hinder the students from accepting the new technology in learning should also be taken into consideration (Mahmod, 2005). Thus, this paper is to identify a) What are the students' perceptions on the use of technology in learning English? and b) What are the factors influencing "e-learning"?

\section{E-learning}

Due to globalization, E-learning has turned into an alternative method to traditional faceto-face education and teaching is no longer restricted to classrooms (Devisakti \& Ramayah, 2019). With the Internet access, it transformed education to a new era technology mediated tools were used to substitute the traditional teaching and learning process that refers to as electronic learning (e-learning) (Yakubu \& Dasuki, 2018). E-learning is currently emerged as the new paradigm in education where it formed a trend in the world. Chalk and talk teaching method is no more a perfect method for teaching and learning whereas e-learning has shift this phenomenon from teacher-centered to learner-centered (Oye et al., 2014). There are few past studies stated that learners are able to access to information and communication through elearning which facilitates them in learning (Peña-Ayala et al., 2014; Nurakun et al., 2018; Yakubu\& Dasuki, 2018).

E-learning is defined as a course that is delivered via Internet to the learners outside the classroom where the teacher is teaching. It is also interactive that the learners will be able to communicate with the teachers in the virtual class. The applications like ZOOM and Google Meet enable the lesson to be delivered live, where the learners could interact with each other in real time. The teachers could easily grade and comment the learners' assignments or tests online to keep track on the learners' progression. E-learning would also transfer skills and knowledge to a large number of recipients at the same time which is impossible for the traditional classroom practice. The learners could easily access to the knowledge with just a click anytime and anywhere. As long as you have a stable Internet connection and usable electronic device, elearning would not be a problem for the users.

According to Iftakhar (2016), Google Classroom as one of the online learning platforms which helps teachers to save time, enhance the interpersonal communication among students and keeps the class in control. Besides, online learning session would be fun if it could be embedded with the game-based learning tools like Quizlet, Kahoot, Plickers and Quizizz which helps the teachers in assessing the students meanwhile attract students' attention with a fun learning environment. These online game-based learning tools have been proved to improve the effectiveness of students' learning process (Chaiyo \& Nokham, 2017; Charalampos, 2019; Zarzycka-Piskorz, 2016).

\section{Method}

According to Hart (1998) as stated in (Al-Emran, Mezhuyev, \& Kamaludin, 2018), information from books and online were both accepted when writing a literature review. This systematic analysis has chosen articles from Eric and Google Scholar from year 2016 to 2020. The intention of the systematic literature review focused on the area of students' perceptions on the use of 
technology in learning English and factors influencing e-learning. The researcher applied the five phases proposed by Khan, Kunz, Kleijnen \& Antes (2003) to conduct a systematic review. This method was used in original research and could help researchers to do analysis, evaluation and synthesis of complex ideas (Khan, Kunz, Kleijnen, \& Antes, 2003).

Figure 1. shows the phases of Systematic Literature Review:

Figure 1. Phase of Systematic Literature Review

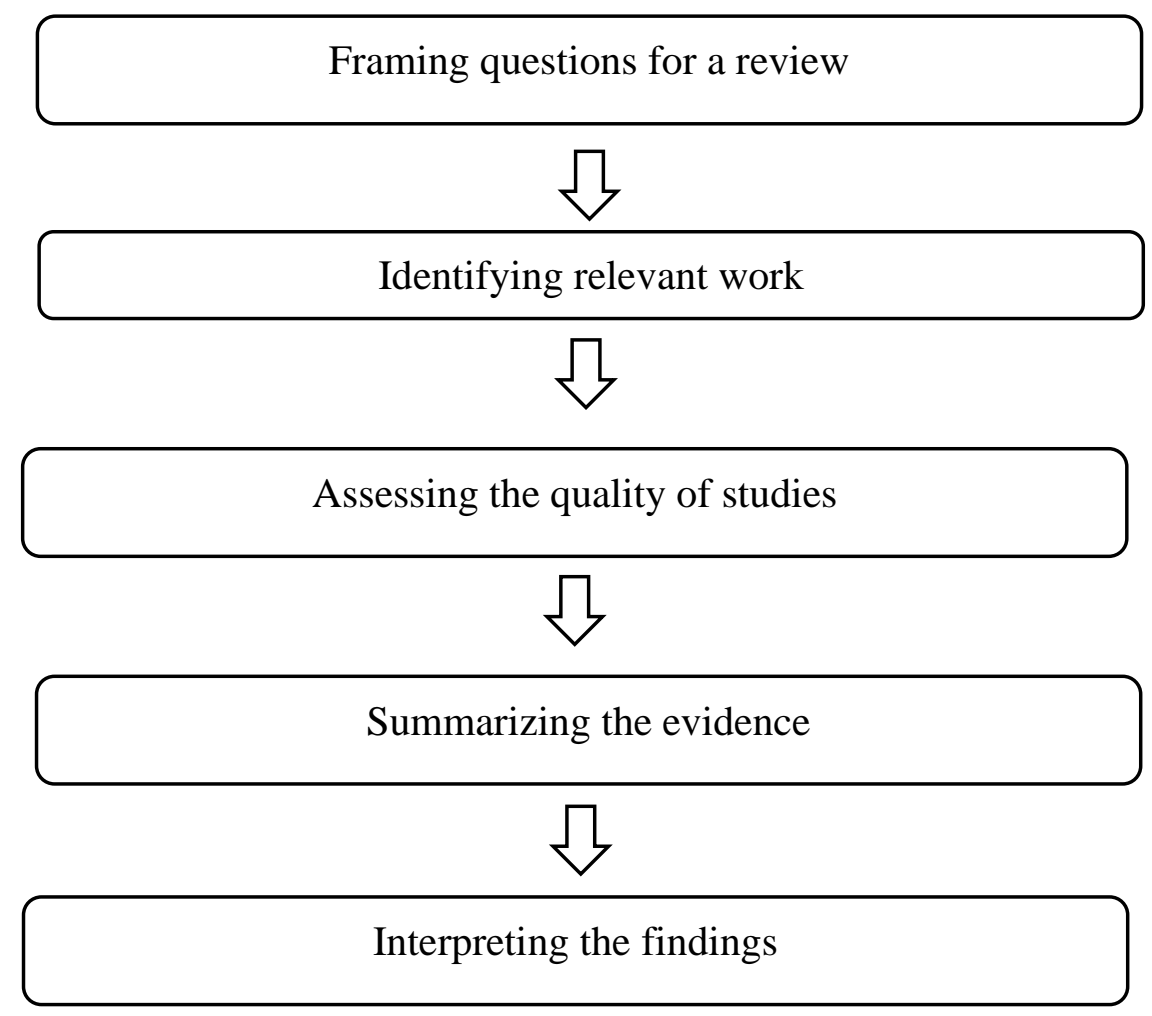

\section{Phase 1: Framing questions for a view}

New technology has expanded learning from traditional classroom to virtual space learning. Thus, this paper is going to examine the students' perceptions and the challenges on the use of technology in learning, published from 2016 to 2020. The research questions are: a) What are the students' perceptions on the use of technology in learning English? b) What are the factors influencing "e-learning"?

\section{Phase 2: Identifying relevant work}

Identifying relevant works consists of two processes for the second phase of systematic review. First, the researcher needs to collect the relevant articles based on the focused topic. Second, the articles need to fit the inclusion and exclusion criteria to be selected. The search was restrained to full-text articles and journal articles to better evaluate between sources (Baran, 2014). The databases used by researcher as comprehensive data collection method in this paper were Google Scholar and Eric. They were used to search for the articles published from 2016 to 2020. The keywords used to search the related articles were "students' perceptions on the use of technology in learning English" and "factors influencing e-learning". 
Vol. 10, No. 1, 2021, E-ISSN: 2226-6348 @ 2021 HRMARS

\section{Phase 3: Assessing the quality of studies}

The researcher must be precise in the selection of articles to make sure the validity of this systematic review. The inclusion and exclusion criteria act as a guideline for the researchers when they are searching for the suitable articles. Table 1 below shows the inclusion and exclusion criteria:

Table 1: Inclusion and Exclusion criteria

\begin{tabular}{ll}
\hline Inclusion criteria & Exclusion criteria \\
\hline Learning English by using technology & Learning English not using technology \\
\hline $\begin{array}{l}\text { Research methodologies: quantitative, } \\
\text { qualitative and mixed method }\end{array}$ & No findings could be found \\
\hline $\begin{array}{l}\text { Sample or respondents from various countries } \\
\text { and levels }\end{array}$ & $\begin{array}{l}\text { Sample or respondents from the same } \\
\text { countries and levels }\end{array}$ \\
\hline $\begin{array}{l}\text { The studies perceive learning using } \\
\text { technology }\end{array}$ & $\begin{array}{l}\text { The studies perceive learning not using } \\
\text { technology }\end{array}$ \\
\hline Factors influencing e-learning & No challenges of e-learning \\
\hline Published between 2016 till 2020 & $\begin{array}{l}\text { The articles were not published between } 2016 \\
\text { till 2020 }\end{array}$ \\
\hline
\end{tabular}

A good research protocol must include both inclusion and exclusion criteria. There are total of 6 criteria for both inclusion and exclusion criteria labelled as the important characteristics to look for the relevant articles that could answer the research questions.

\section{Phase 4: Summarising the evidence}

All of the relevant articles are found in Google Scholar and Eric database. There are total of 200 articles found in Google Scholar and Eric with the search using keywords "students' perceptions on the use of technology in learning English" and "factors influencing e-learning". After the researcher chose and sorted the articles with 104 non-English texts (96 remained), 83 articles which were removed based on the inclusion and exclusion criteria, finally 21 articles were selected to be included in this paper.

\section{Phase 5: Interpreting the findings}

Lastly, the findings were interpreted and analysed. The data was catogorise by using content analysis which are qualitative, quantitative and mixed method. A total of 21 articles on students' perceptions on the use of technology in learning English and factors influencing e-learning were selected after the selection process. Table 2 shows the analysis method used by the 21 selected articles from year 2016 to 2020 . From the table, qualitative method was the least used method whereas quantitative was the most used method and followed by mixed method. 
INTERNATIONAL JOURNAL OF ACADEMIC RESEARCH IN PROGRESSIVE EDUCATION AND

DEVELOPMENT

Vol. 10, No. 1, 2021, E-ISSN: 2226-6348 @ 2021 HRMARS

Table 2: Numbers of Study Based on Methods

Methods: Google Scholar and Eric

\begin{tabular}{ll}
\hline Quantitative & 13 \\
\hline Mixed method & 5 \\
\hline Qualitative & 3 \\
\hline
\end{tabular}

\section{Results}

Twenty-one studies reported on the students' perceptions on the use of technology in learning English and factors influencing e-learning from the year 2016 to 2020 had been identified (see Table 3). 
INTERNATIONAL JOURNAL OF ACADEMIC RESEARCH IN PROGRESSIVE EDUCATION AND DEVELOPMENT

Vol. 10, No. 1, 2021, E-ISSN: $2226-6348$ @ 2021 HRMARS

Table 3 Overview of selected studies

\begin{tabular}{|c|c|c|c|c|}
\hline & Authors & Country & Primary data sources & Respondents \\
\hline 1 & Sharma (2019) & $\begin{array}{l}\text { Saudi } \\
\text { Arabia }\end{array}$ & Questionnaire & $\begin{array}{l}60 \text { Saudi } \quad E F L \\
\text { learners }\end{array}$ \\
\hline 2 & Shouma (2019) & Canada & Questionnaire and Interview & $\begin{array}{l}45 \text { young adult ESL } \\
\text { learners and their } \\
11 \text { teachers }\end{array}$ \\
\hline 3 & Istifci (2017) & Turkey & Questionnaire and Interview & 167 students \\
\hline 4 & Zinan\& Sai (2017) & China & Questionnaire & 200 students \\
\hline 5 & $\begin{array}{l}\text { Gyamfi\& } \\
\text { Sukseemuang } \\
(2017)\end{array}$ & Thailand & $\begin{array}{l}\text { Questionnaire and semi- } \\
\text { structured focus group } \\
\text { interview }\end{array}$ & 340 EFL learners \\
\hline 6 & Mutambik (2018) & $\begin{array}{l}\text { Saudi } \\
\text { Arabia }\end{array}$ & group interviews & $\begin{array}{l}16 \text { students and } 8 \\
\text { teachers }\end{array}$ \\
\hline 7 & $\begin{array}{ll}\text { Rivera } & \text { Barreto } \\
(2018) & \\
\end{array}$ & Colombia & $\begin{array}{l}\text { field diary, an online forum, a } \\
\text { survey, and students' artifacts }\end{array}$ & 16 students \\
\hline 8 & $\begin{array}{l}\text { Ngo\& } \\
\text { Eichelberger } \\
(2019) \\
\end{array}$ & USA & Questionnaire & 928 students \\
\hline 9 & $\begin{array}{l}\text { Chou, Shen, } \\
\text { Hsiao, Shen\& } \\
\text { Shen (2019) }\end{array}$ & Taiwan & Questionnaire & 702 students \\
\hline 10 & $\begin{array}{l}\text { Nilayon\& } \\
\text { Brahmakasikara } \\
(2018)\end{array}$ & Thailand & $\begin{array}{ll}\text { social media } & \text { sites, self- } \\
\text { reflection } & \\
\text { reports, } & \text { researcher's } \\
\text { observation, } & \\
\text { interview } & \\
\end{array}$ & 81 students \\
\hline 11 & Abu-Ayfah (2020) & $\begin{array}{l}\text { Saudi } \\
\text { Arabia }\end{array}$ & Questionnaire & 300 students \\
\hline 12 & $\begin{array}{l}\text { Klimova\& } \\
\text { Polakova (2020) }\end{array}$ & Czechia & Questionnaire & 28 students \\
\hline 13 & $\begin{array}{l}\text { Al-Azawei, } \\
\text { Parslow\& } \\
\text { Lundqvist (2016) } \\
\end{array}$ & Iraq & $\begin{array}{l}\text { Questionnaire, } \\
\text { structured interviews, and } \\
\text { focus groups }\end{array}$ & 108 respondents \\
\hline 14 & $\begin{array}{l}\text { Naveed, } \\
\text { Muhammad, } \\
\text { Sanober, } \\
\text { Qureshi\& Shah } \\
(2017)\end{array}$ & $\begin{array}{l}\text { Saudi } \\
\text { Arabia }\end{array}$ & Questionnaire & 247 participants \\
\hline
\end{tabular}


INTERNATIONAL JOURNAL OF ACADEMIC RESEARCH IN PROGRESSIVE EDUCATION AND DEVELOPMENT

Vol. 10, No. 1, 2021, E-ISSN: 2226-6348 @ 2021 HRMARS

\begin{tabular}{lllll}
\hline 15 & $\begin{array}{l}\text { Malufu, } \\
\text { Muchemwa\& } \\
\text { Malufu (2016) }\end{array}$ & Zimbabwe & Questionnaire & 65 respondents \\
\hline 16 & $\begin{array}{l}\text { Xhaferi, Bahiti\& } \\
\text { Farizi (2018) }\end{array}$ & $\begin{array}{l}\text { Macedoni } \\
\text { a }\end{array}$ & Questionnaire & 314 students \\
\hline 17 & $\begin{array}{l}\text { Chen\& Yao } \\
\text { (2016) }\end{array}$ & Malaysia & Questionnaire & 100 students \\
\hline 18 & Al-Juda (2017) & $\begin{array}{l}\text { Saudi } \\
\text { Arabia }\end{array}$ & Questionnaire & 500 students \\
\hline 19 & $\begin{array}{l}\text { Ahmed, Hussain\& } \\
\text { Farid (2018) }\end{array}$ & Pakistan & Questionnaire & 400 students \\
\hline 20 & $\begin{array}{l}\text { Taat\& Francis } \\
\text { (2020) }\end{array}$ & Malaysia & Questionnaire & 230 students \\
\hline 21 & Sriwichai (2020) & Thailand & $\begin{array}{l}\text { Questionnaire and focus group } \\
\text { interview }\end{array}$ & 364 students \\
\hline
\end{tabular}

\section{Students' Perceptions on the Use of Technology in Learning English}

Majority of the results showed that the students' perceptions on the use of technology in learning English in the scope of learnability, usability, motivation, and willingness (Shouma, 2019).

Table 4: Students' Perceptions on the Use of Technology in Learning English

\begin{tabular}{lll}
\hline No. & Authors & Discussion \\
\hline 1 & Sharma (2019) & $\begin{array}{l}\text { Learners used the social media for social communication, fun and } \\
\text { educational learning which have shown a tremendous interest } \\
\text { towards the online learning. }\end{array}$ \\
\hline 2 & Shouma (2019) & $\begin{array}{l}\text { Both students and teachers show positive view on the use of target } \\
\text { technology across the four themes: learnability, usability, } \\
\text { motivation, and willingness. }\end{array}$ \\
\hline 3 & Istifci (2017) & $\begin{array}{l}\text { Instant feedback and independent study technique provided by } \\
\text { online learning were favored by most of the participants. }\end{array}$ \\
\hline 4 & $\begin{array}{l}\text { Zinan\& } \\
\text { (2017) }\end{array}$ & $\begin{array}{l}\text { The EFL students stated that ICT was well-integrated into the College } \\
\text { English Course. }\end{array}$ \\
\hline 5 & $\begin{array}{l}\text { Gyamfi\& } \\
\text { Sukseemuang } \\
\text { (2017) }\end{array}$ & $\begin{array}{l}\text { The learners agreed to the usefulness of online learning program Tell } \\
\text { Me More for practicing and improving their listening skills. }\end{array}$ \\
\hline 6 & $\begin{array}{l}\text { Mutambik } \\
\text { (2018) }\end{array}$ & $\begin{array}{l}\text { E-learning in studying EFL provides chances to develop speaking and } \\
\text { listening skills of students. }\end{array}$ \\
\hline 7 & $\begin{array}{l}\text { Rivera } \\
\text { (2018) }\end{array}$ & $\begin{array}{l}\text { Students foster the language and raising interest in developing other } \\
\text { skills by using ICT. }\end{array}$ \\
\hline 8 & $\begin{array}{l}\text { Ngo\& } \\
\text { Eichelberger } \\
\text { (2019) }\end{array}$ & $\begin{array}{l}\text { Most of the learners feel that EFL learning with ICT is good for their } \\
\text { receptive English skills rather than that of their expressive skills. }\end{array}$ \\
\hline
\end{tabular}


Vol. 10, No. 1, 2021, E-ISSN: 2226-6348 @ 2021 HRMARS

\begin{tabular}{|c|c|c|}
\hline 9 & $\begin{array}{l}\text { Chou, Shen, } \\
\text { Hsiao, Shen\& } \\
\text { Shen (2019) }\end{array}$ & $\begin{array}{l}\text { The "perceived enjoyment" and "perceived usefulness" are } \\
\text { positively established in the study. }\end{array}$ \\
\hline 10 & $\begin{array}{l}\text { Nilayon\& } \\
\text { Brahmakasikara } \\
(2018)\end{array}$ & $\begin{array}{l}\text { Participants believed the use of technology in improving speaking } \\
\text { skills and confidence. }\end{array}$ \\
\hline 11 & $\begin{array}{l}\text { Abu-Ayfah } \\
\text { (2020) }\end{array}$ & $\begin{array}{l}\text { Majority of the students favor in using telegram to improve language } \\
\text { skill especially vocabulary. }\end{array}$ \\
\hline 12 & $\begin{array}{l}\text { Klimova\& } \\
\text { Polakova (2020) }\end{array}$ & Students perceive the mobile app as facilitative for learning actions. \\
\hline
\end{tabular}

\section{Factors Influencing E-Learning}

Positive reviews on the implementation of technology in learning English have reported in most of the studies. However, there are also factors that influencing E-learning. (see Table 5)

Table 5: Factors Influencing E-Learning

\begin{tabular}{|c|c|c|}
\hline No. & Authors & Discussion \\
\hline 1 & $\begin{array}{l}\text { Al-Azawei, } \\
\text { Parslow\& } \\
\text { Lundqvist (2016) } \\
\end{array}$ & $\begin{array}{l}\text { Inadequate training programs and insufficient ICT infrastructure } \\
\text { are the key issues distinguished by most of the participants. }\end{array}$ \\
\hline 2 & $\begin{array}{l}\text { Naveed, } \\
\text { Muhammad, } \\
\text { Sanober, Qureshi\& } \\
\text { Shah (2017) }\end{array}$ & $\begin{array}{l}\text { Student, Instructor, Design and Contents, System and } \\
\text { Technological dimensions, and Institutional Management Service } \\
\text { are the most significant factors that affect E-Learning. }\end{array}$ \\
\hline 3 & $\begin{array}{l}\text { Malufu, } \\
\text { Muchemwa\& } \\
\text { Malufu (2016) }\end{array}$ & $\begin{array}{l}\text { The lecturer's competence, lecturer's attitude towards learning } \\
\text { and nature of the subject are the factors that hinder the adoption } \\
\text { of e-learning. }\end{array}$ \\
\hline 4 & $\begin{array}{l}\text { Xhaferi, Bahiti\& } \\
\text { Farizi (2018) }\end{array}$ & $\begin{array}{l}\text { The variables of Attitudes, Perception about ICT and ICT } \\
\text { Competence from TAM model are identified as the factors effect } \\
\text { on Prediction of the E-Learning. }\end{array}$ \\
\hline 5 & Chen\& Yao (2016) & $\begin{array}{l}\text { The main factors that affect e-learning are perceive of usefulness } \\
\text { and ease of use. }\end{array}$ \\
\hline 6 & Al-Juda (2017) & $\begin{array}{l}\text { Instructions, guidelines and manual at the web which related to } \\
\text { ease of the e-learning system and easy access to lecturers are the } \\
\text { factors that influence students' perception on e-learning. }\end{array}$ \\
\hline 7 & $\begin{array}{l}\text { Ahmed, Hussain\& } \\
\text { Farid (2018) }\end{array}$ & $\begin{array}{l}\text { Challenges of e-learning in Pakistan are non-availability of } \\
\text { specialized contents, electricity shortfall, English language } \\
\text { competency, and dependency on teacher. }\end{array}$ \\
\hline 8 & $\begin{array}{l}\text { Taat\& } \\
(2020)\end{array}$ & $\begin{array}{l}\text { The technical support like Internet and broadband services are the } \\
\text { main concern of the students. }\end{array}$ \\
\hline
\end{tabular}


Vol. 10, No. 1, 2021, E-ISSN: 2226-6348 @ 2021 HRMARS

\begin{tabular}{l}
9 Sriwichai (2020) \\
$\begin{array}{l}\text { Factors that identified in the study are lack of skills, limited } \\
\text { accessibility, large class size, difficulty of online interaction, } \\
\text { Internet problem and time management of the students }\end{array}$ \\
\hline
\end{tabular}

\section{Discussion}

Previous studies have highlighted discussion on learners' perceptions with the use of technology in learning English and factors influencing e-learning. The result from the systematic review shows that most of the users agreed with the use of technology does help in learning English (Sharma, 2019; Istifci, 2017; Chou et al., 2019; Abu-Ayfah, 2020). E-learning provided a new platform for learners to enjoy face-to-face education anywhere and at any time which the learners can get the immediate response and enjoy their independent study (Istifci, 2017). ESL and EFL learners could be effortlessly obtain authentic visual and audio interactive materials online with native speakers to assist in their English learning. Furthermore, the cost of physical infrastructure like classroom is spared as this learning method supported wireless learning and facilitate learning actions (Klimova \& Polakova, 2020). Learning with technology is believed to enhance speaking and listening skills as well as confidence of the learners (Mutambik, 2018; Nilayon\& Brahmakasikara, 2018; Gyamfi\& Sukseemuang,2017) Besides, most of the users agreed that e-learning does motivate learners' interest in learning English (Sharma, 2019; Abu-Ayfah, 2020).

However, in order to find out the usefulness of e-learning, there was a research model proposed by Sun et al. (2008) to know about the causes influencing learners' satisfaction toward e-learning (Chen\& Yao,2016). The major drawbacks like interactions between students in classrooms and the low-accomplishment task rate proposed that e-learning was doubtful to be the most useful teaching and learning strategy (Glazer, 2012; Reich, 2015). The most important support for online learning will be the ICT infrastructure mainly the Internet and broadband (AIAzawei, Parslow\& Lundqvist,2016; Taat\& Francis,2020). Without Internet it will hinder successful application of e-learning which agreed by many lecturers $(22.97 \%)$ and most of the students (62.5\%) in Iraq (Al-Azawei, Parslow\& Lundqvist, 2016). In addition, internal factors like attitudes, perception about ICT and ICT competence were also the factors effect on prediction of the esLearning (Xhaferi, Bahiti\& Farizi, 2018). The facilitator of the online learning should equip with skills and show positive attitudes that could nature the subject and improve e-learning (Malufu, Muchemwa\& Malufu, 2016; Ahmed, Hussain\& Farid, 2018). Besides, the factors like ease of the e-learning system (Al-Juda, 2017) and good institutional management service (Naveed, Muhammad, Sanober, Qureshi\& Shah,2017) could also affect the learners' perception towards elearning system.

\section{Conclusion}

Learning with technology is a learning concept that provides a virtual learning space for all the learners. There are various of options to help develop the teaching and learning methods in the classroom by using technology. In this paper, the students' perceptions on the use of technology in learning English and the factors influencing e-learning are being identified. Most of the students believed and agreed to the usefulness of online learning. They engaged in learning English with technology and have confidence to perform well in their learning. The students enjoy 
learning English with technology as the audio and visual support from the internet are good to help them in speaking and listening skills. Nonetheless, factors that hinder the learners from trusting the technology in learning should also be aware of. Lack of interactions between the students could hinder students from learning successfully and enthusiastically. Internet is one of the main sources for learning using technology, thus the poor internet connection might impede the process of e-learning and affect the outcomes. The role of teaching assistants is important in e-learning as they are acting like a facilitator to the students, thus they should always equip with the professional development of e-learning. Other than that, the teaching assistants could assign some online project works to the students in order to help them learn better in group discussing and brainstorming skills. Students who stay in rural area might have internet problem when they are learning online, thus the time allocation for their online project could be more flexible to lessen students' burden. In conclusion, the implementation of e-learning in teaching and learning process could help to increase the quality of education if the users take considerations on the factors influencing e-learning. This paper suggests that education authorities should revisit elearning policies to resolve and prevent the factors that might impede the integration of elearning. Future studies could compare students' perceptions on the use of technology in learning English and their success rate based on the four language skills.

\section{References}

Abu-Ayfah, Z. A. (2020). Telegram App in Learning English: EFL Students' Perceptions. English Language Teaching, 13(1), 51-62.

Ahmed, M. U., Hussain, S., \& Farid, S. (2018). Factors Influencing the Adoption of e-Learning in an Open and Distance Learning Institution of Pakistan. Electronic Journal of $e$ Learning, 16(2), 148-158.

Al-Azawei, A., Parslow, P., \& Lundqvist, K. (2016). Barriers and opportunities of e-learning implementation in Iraq: A case of public universities. The International Review of Research in Open and Distributed Learning, 17(5).

Al-Emran, M., Mezhuyev, V., \& Kamaludin, A. (2018). Technology Acceptance Model in Mlearning context: A systematic review. Computers \& Education, 125, 389-412.

Al-Juda, M. Q. B. (2017). Distance Learning Students' Evaluation of E-Learning System in University of Tabuk, Saudi Arabia. Journal of Education and Learning, 6(4), 324-335.

Bancheri, S. (2006). A language teacher's perspective on effective courseware. In Randall PD and Margaret AH (Eds). Changing Language Education through CALL, (pp.31-47). New York: Routledge.

Baran, E. (2014). A review of research on mobile learning in teacher education. Educational Technology and Society.

Chaiyo, Y., \& Nokham, R. (2017). The effect of Kahoot, Quizizz and Google Forms on the student's perception in the classrooms response system. International Conference on Digital Arts, Media and Technology, (pp. 178-182). Chiang Mai.

Charalampos, C. (2019). Enabling active learning in large classes through the use of Plickers. 5th International Conference on Higher Education Advance. Valencia. 
Chen, W. S., \& Yao, A. Y. T. (2016). An empirical evaluation of critical factors influencing learner satisfaction in blended learning: A pilot study. Universal Journal of Educational Research, 4(7), 1667-1671.

Chou, C. M., Shen, C. H., Hsiao, H. C., Shen, T. C., \& Shen, T. C. (2019). An Investigate of Influence Factor for Tertiary Students' M-Learning Effectiveness: Adjust Industry 4.0 \& 12-Year Curriculum of Basic Education. International Journal of Psychology and Educational Studies, 6(2), 66-76.

Devisakti, A., \& Ramayah, T. (2019). E-Learning Usage Outcomes among University Learners: A Pilot Study. Journal of Education and e-Learning Research, 6(3), 149-155.

Glazer, F. S. (2012). What continues to impress me about blended learning is its versatility: The instructional design of a course can vary dramatically to reflect the style of the instructor and the nature of the discipline. Common to all successful blended learning courses, though, is active learning in one form or another and, of course, an increased use of technology. The blended learning courses we have seen all incorporate more interactions, among the students and between students and the instructor. Blended Learning: Across the Disciplines, Across the Academy, 127.

Gyamfi, G., \& Sukseemuang, P. (2017). EFL Learners' Perceptions, Practices and Achievement with the Online Learning Program" Tell Me More". Contemporary Educational Technology, 8(4), 338-358.

Heflin, H., Shewmaker, J., \& Nguyen, J. (2017). Impact of mobile technology on student attitudes, engagement, and learning. Computers\& Education, 107, 91-99.

Iftakhar, S. (2016). Google Classroom: What works and how. Journal of Education and Social Sciences 3(1): 12-18.

Istifci, I. (2017). Perceptions of Turkish EFL Students on Online Language Learning Platforms and Blended Language Learning. Journal of Education and Learning, 6(1), 113-121.

Khan, K. S., Kunz, R., Kleijnen, J., \& Antes, G. (2003). Five steps to conducting a systematic review. Journal of the Royal Society of Medicine.

Klimova, B., \& Polakova, P. (2020). Students' perceptions of an EFL vocabulary learning mobile application. Education Sciences, 10(2), 37.

Lin, C. P., \& Yunus, M. M. (2012). ESL Teacher and ICT: Teachers' Perception. Advances in Language and Literary Studies, 3(1), 119-128.

Liton, H. A. (2014). Exploring Teachers' Attitude towards ICT integration into ESP and EFL Classroom. International Journal of Instructional Technology and Distance Learning, 11(5), 3-18.

Makokha, G. L., \& Mutisya, D. N. (2016). Status of e-learning in public universities in Kenya. International review of research in open and distributed learning, 17(3), 341-359.

Malufu, K., Muchemwa, S., \& Malufu, S. (2016). A comparative study of the factors influencing the adoption of E-learning by lecturers at universities in Bulawayo, Zimbabwe. IOSR Journal of Research \& Method in Education, 6, 64-73.

Mutambik, I. (2018). The Role of e-Learning in Studying English as a Foreign Language in Saudi Arabia: Students' and Teachers' Perspectives. English Language Teaching, 11(5), 74-83. 
Naveed, Q. N., Muhammad, A., Sanober, S., Qureshi, M. R. N., \& Shah, A. (2017). A mixed method study for investigating critical success factors (CSFs) of e-learning in Saudi Arabian universities. methods, $8(5)$.

Ngo, H., \& Eichelberger, A. (2019). College students' attitudes toward ICT use for English learning. International Journal of Education and Development using ICT, 15(1).

Nilayon, N., \& Brahmakasikara, L. (2018). Using Social Network Sites for Language Learning and Video Conferencing Technology to Improve English Speaking Skills: A Case Study of Thai Undergraduate Students. LEARN Journal: Language Education and Acquisition Research Network, 11(1), 47-63.

Nurakun, K. Z., Ismailova, R., and Dündar, H. (2018). Learning management system implementation: A case study in the Kyrgyz Republic. Interactive Learning Environments, 26(8): 1010-1022.

Prensky, M. (2001). Digital Natives, Digital Immigrants. On the Horizon, 1-6.

Reich, J. (2015). Rebooting MOOC research. Science, 347(6217), 34-35.

Barreto, R. A. M. (2018). Motivating English Language Use by Using the Benefits of Technology. GiST Education and Learning Research Journal, 16, 117-140.

Selwyn, N. (2003). ICT in non-formal youth and adult education: defining territory. OECD/NCAL International roundtable, Philadelphia. Retrieved September, 18, 2008.

Sharma, V. (2019). Saudi Students' Perspective on Social Media Usage to Promote EFL Learning. International Journal of Linguistics, Literature and Translation, 2(1), 290200.

Shouma, A., \& Cardoso, W. (2019). Tablets in second language learning: learners' and teachers' perceptions. CALL and complexity-short papers from EUROCALL 2019, 340.

Sriwichai, C. (2020). Students' Readiness and Problems in Learning English through Blended Learning Environment. Asian Journal of Education and Training, 6(1), 23-34.

Stephenson, J. (2018). Teaching \& Learning Online: New Pedagogies for New Technologies. New York: Routledge.

Stepp-Greany, J. (2002). Student perceptions on language learning in a technological environment: Implications for the new millennium. Language Learning \& Technology, 6(1), 165-180.

Sun, P. C., Tsai, R. J., Finger, G., Chen, Y. Y., \& Yeh, D. (2008). What drives a successful e-Learning? An empirical investigation of the critical factors influencing learner satisfaction. Computers \& education, 50(4), 1183-1202.

Taat, M. S., \& Francis, A. (2020). Factors Influencing the Students' Acceptance of E-Learning at Teacher Education Institute: An Exploratory Study in Malaysia. International Journal of Higher Education, 9(1).

Xhaferi, G., Bahiti, R., \& Farizi, A. (2018). Analysis of Students Factors Influencing the Integration of E-Learning in Higher Education. Case Study: University of Tetovo. European Journal of Engineering and Formal Sciences, 2(2), 90-95.

Yakubu, M. N., and Dasuki, S. I. (2018). Factors affecting the adoption of e-learning technologies among higher education students in Nigeria: A structural equation modelling approach. Information Development, 35(3): 492-502.

Zarzycka-Piskorz, E. (2016). Kahoot it or not? Can games be motivating in learning grammar? Teaching English with Technology 16(3): 17-36. 
INTERNATIONAL JOURNAL OF ACADEMIC RESEARCH IN PROGRESSIVE EDUCATION AND DEVELOPMENT

Vol. 10, No. 1, 2021, E-ISSN: 2226-6348 @ 2021 HRMARS

Zinan, W., \& Sai, G. T. B. (2017). STUDENTS'PERCEPTIONS OF THEIR ICT-BASED COLLEGE ENGLISH COURSE IN CHINA: A CASE STUDY. Teaching English with Technology, 17(3), 53-76. 